\title{
PRODUCTION AND CHARACTERIZATION OF BAMBOO PELLETS
}

\author{
PRODUÇÃO E CARACTERIZAÇÃO DE PELLETS DE BAMBU
}

\section{Carlos Roberto SETTE JR ${ }^{1}$; Paola de Castro e FREITAS ${ }^{2}$; Vanessa Pereira FREITAS ${ }^{3}$; Fábio Minoru YAMAJI ${ }^{4}$; Rogério de Araújo ALMEIDA ${ }^{5}$}

1. Professor Doutor do curso de Engenharia Florestal, Universidade Federal de Goiás - UFG, Goiânia, GO, Brasil. crsettejr@hotmail.com; 2. Engenheira Florestal, Mestre em Agronomia, Universidade Federal de Goiás - UFG, Goiânia, GO, Brasil; 3. Engenheira Florestal, Universidade Federal de Goiás - UFG, Goiânia, GO, Brasil; 4. Professor Doutor do curso de Engenharia Florestal, Universidade Federal de São Carlos - UFSCar, Sorocaba, SP, Brasil; 5. Professor Doutor do curso de Agronomia, Universidade Federal de Goiás - UFG, Goiânia, GO, Brasil.

\begin{abstract}
Agroforestry biomass is a great energy alternative, with potential to produce pellets and briquettes. The objective of this study was to assess the potential of using the biomass of bamboo species to produce pellets. Mature culms of the species Bambusa vulgaris var. Vitatta, Dendrocalamus asper and Bambusa tuldoides were used, in addition to wood discs of 6 year-old hybrids of E. urophylla $x$ E. grandis for comparative purposes. Biomass was characterized by the bulk density, proximate analysis, calorific value and energy density. Pellets were characterized (moisture content, length, diameter, durability, bulk, apparent and energy density) after production. All the characteristics of bamboo and eucalyptus pellets met the quality specifications required in international product marketing standards, except for the ash levels. The species Bambusa vulgaris var. vitatta, Dendrocalamus asper and Bambusa tuldoides had energy characteristics that indicate its potential for being used as an energy source in the form of pellets.
\end{abstract}

KEYWORDS: Bioenergy. Densification of biomass. Energy potential.

\section{INTRODUCTION}

Biomass is one of the renewable energy sources with the greatest potential for development in the next years, and is considered one of the main options to diversify energy sources and reduce dependence on fossil fuels (ANEEL, 2013). The energy and rational use of biomass tends to promote the development of economically disadvantaged regions, through job creation and income generation, reducing the problem of rural exodus and dependence on foreign energy (LYBEER, 2006). Such energy and rational use of biomass is of great environmental importance for reducing the use of fossil fuels and the emission of Greenhouse Effect Gases, consequently, mitigating global warming.

Wood and agricultural crops (e.g., sugar cane) are the main energy biomass sources currently used in Brazil (GARCIA, et al., 2013). However, alternative biomass sources with the potential for power generation, such as agricultural/forest residues and grasses, have been used and are the focus of studies on the substitution of fossil fuels and natural gas. Bamboo species are among the alternative fuels studied, and have a high growth rate and accelerated biomass production that places them in a prominent position for energy use (SCURLOCK et al., 2000).

The estimated area planted with bamboo species in the world is 40 million hectares
(LOBOVIKOV et al., 2007). In Brazil, the large forest stands with bamboo are located in the states of Maranhão, Piauí, Pernambuco, Paraíba and Bahia, and are intended primarily to provide biomass and cellulose (SANTI, 2015). The species Dendrocalamus asper (Schult. \& Schult.) Backer ex. K. Heynek (MOGNON et al., 2015), Bambusa vulgaris Schard. ex J.C. Wendl and Bambusa tuldoides Munro (SANTANA, 2014) are highlighted as the most common and widespread exotic tropical species of bamboo in the country, and have a great potential due to its rapid growth and significant biomass. However, the limited scientific knowledge on bamboo species, especially regarding the possibility of its use as an energy source, has restricted the full development of the culture.

The pellets are among the possible biomass energy sources most widely used in the world (TOSCANO et al., 2013; ARRANZ et al., 2015). Pellets have characteristics superior to other biomass products, such as woodchips and briquettes, especially in regards to mass and energy densities (ARRANZ et al., 2015). Such higher density results in lower transportation costs and greater efficiency in regards to energy conversion (CARONE et al., 2011), having suitable properties for use in residential and industrial scale.

World pellet production had an accelerated growth in recent years, of 7 to 19 million tons from 2006 to 2012 (FAO, 2012), mainly due to the increased demand generated by environmental 
policies and bioenergy use goals in Europe (DUCA et al., 2014). Pellet production in Brazil is evolving slowly, largely because of the little information on the product and the industry, with a small-scale production in 14 factories of 60,000 ton/year (ABIPELL, 2013) intended mainly to the thermal market (ESCOBAR, et al., 2014).

The biomass of pellets has been widely studied worldwide (LIU et al., 2014). However, scientific studies that evaluated the production of pellets from the biomass of bamboo species and their characteristics (LIU et al., 2012, 2013, 2014) are rare. The development of new research projects given the increasing demand for renewable energy from biomass is essential. The objective of this study was to evaluate the potential of using bamboo species biomass to produce pellets.

\section{MATERIAL AND METHODS}

\section{Selection, collection and preparation of samples}

Mature culms of the species Bambusa vulgaris var. vulgaris, Dendrocalamus asper and Bambusa tuldoides, in an area of 5-year old experimental, were selected and collected in clumps in the central state of Goiás. The altitude in the region is $730 \mathrm{~m}$, and the climate is type Aw (hot and semi-humid) according to the Köppen classification, with a well-defined dry season from May to September, average annual precipitation of 1.400 $\mathrm{mm}$ and soil characterized as dark Oxisol. The criteria defined by Hidalgo-Lopez (2003) were considered to select mature culms: placed in the center of the thicket, with high hardness and dark color. A total of five culms were randomly chosen for each species, and $30 \mathrm{~cm}$ samples near the DBH (1.3 meters high) and between the nodes were made through cutting.

A total of five trees of 6-year-old Eucalyptus grandis $x$ Eucalyptus urophylla hybrids (popularly known as eucalyptus urograndis) were selected from a forest plantation located in the same area used to sample bamboo culms, for comparison. These five trees were cut and pruned, and short logs of $30 \mathrm{~cm}$ in length were cut in the trunk near the DBH (1.3 meters high).

Bamboo and eucalyptus samples were used to characterize biomass and production of pellets, which were transformed into sawdust using a crusher and a Wiley knife mil, and mechanically separated in the orbital shaker of sieves with intermittent beats, to select the faction removed in the sieve (number 24 international, with mesh opening of 60).

\section{Evaluation of biomass characteristics}

The procedures carried out to evaluate biomass characteristics were performed in triplicate to obtain the arithmetic mean (ARRANZ et al., 2015). The proximate analysis is based on the ABNT NBR 8112 (BRAZILIAN ASSOCIATION OF TECHNICAL STANDARDS; ASSOCIAÇÃO BRASILEIRA DE NORMAS TÉCNICAS - ABNT, 1983), where ash content, volatiles, fixed carbon were determined.

The bulk density of the biomass was obtained according to the methods established in ABNT NBR 6922 (BRAZILIAN ASSOCIATION OF TECHNICAL STANDARDS; ASSOCIAÇÃO BRASILEIRA DE NORMAS TÉCNICAS - ABNT, 1981). The relationship between the mass of the biomass and the known volume of a container was used.

The highest calorific value was determined using a calorimeter bomb (IKA WORKS, model C200), as established by ABNT NBR 8633 (BRAZILIAN ASSOCIATION OF TECHNICAL STANDARDS; ASSOCIAÇÃO BRASILEIRA DE NORMAS TÉCNICAS - ABNT, 1984), and the energy density was calculated multiplying the gross calorific value by the bulk density of biomass.

\section{Pellets production and evaluation}

The bamboo and eucalyptus pellets were produced using a laboratory pelletizer, consisting of a lower part with a circular matrix with $6 \mathrm{~mm}$ holes and an upper part with two rolls with rotational movements (around its axis and around the matrix). The bottom of the matrix also has a blade which cuts the pellets into a standard size of $30 \mathrm{~mm}$. The moisture content of two kilograms of biomass of each species was adjusted to $20 \%$ for the pellet production process, as recommended by the manufacturer of the equipment.

First, with the objective to determinate average dimensions, moisture content and density apparently individual, thirty pellets of each species were randomly selected. The length $(\mathrm{L}$ in $\mathrm{mm})$ and diameter $(\mathrm{d}$ in $\mathrm{mm})$ were measured using a digital caliper and the initial mass was determined, right after production (Mi in $\mathrm{g}$ ) and final mass (Mf in $\mathrm{g}$ ), after drying in an oven at $103^{\circ} \mathrm{C}$ and stabilizing.

The moisture content of each pellet (U\%) was obtained using equation 1, and following ABNT NBR 14929 (BRAZILIAN ASSOCIATION OF TECHNICAL STANDARDS; ASSOCIAÇÃO BRASILEIRA DE NORMAS TÉCNICAS - ABNT, 2003).

$U \%=\frac{(M i-M f)}{M f} \times 100$ 
The apparent density of each pellet $\left(\mathrm{d}_{\mathrm{ap}}\right.$ in g. $\mathrm{cm}^{-3}$ ) was obtained using equation 3 , whereas the individual volume $\left(\mathrm{V}\right.$ in $\left.\mathrm{cm}^{3}\right)$ was determined by equation 2 .

$$
\begin{aligned}
& V=\frac{\pi}{4 d^{\pi^{2}} L} \\
& d_{a p}=\frac{M i}{V}
\end{aligned}
$$

The bulk density $\left(d_{\text {bulk }}\right.$ in $\left.\mathrm{g} . \mathrm{cm}^{-3}\right)$ of the pellets was calculated as the ratio of the pellet mass $\left(\mathrm{m}_{\mathrm{p}}\right.$ in $\left.\mathrm{g}\right)$ and the volume of a container $\left(\mathrm{V}_{\mathrm{c}}\right.$ in $\left.\mathrm{cm}^{3}\right)$, using equation 4 . The pellets were placed in a container, and then were weighed using a digital precision scale. The volume of the container was determined using its length and diameter.

$d_{b u l k}=\frac{m_{p}}{v_{T}}$

The durability of the pellets $\left(\mathrm{P}_{\mathrm{d}}\right.$ in \%) was determined as the loss of mass of the samples (see Toscano et al. 2013 and Liu et al. 2014) and using equation 5. A total of twenty pellets of each species were weighed to obtain the initial mass $\left(\mathrm{m}_{\mathrm{id}}\right.$ in $\mathrm{g}$ ) and moved to a vibrating sieve for 10 minutes, at 80 rotations per minute. After this procedure, the pellets were weighed once again, when the final mass was obtained $\left(\mathrm{m}_{\mathrm{fd}}\right.$ in $\left.\mathrm{g}\right)$.

$$
p d=100-\left[\frac{m_{i d}-m_{f d}}{m_{i d}} \times 100 \%\right]
$$

The energy density was calculated multiplying the highest calorific value of the biomass by the apparent density of the pellets.

\section{Statistical data analysis}

A completely randomized design with four treatments (species) was used in the statistical analysis of the results obtained. Analyses were carried out in the software JMP (SAS INSTITUTE, 1997), and the outliers and heterogeneity of variance were assessed. An Analysis of Variance (ANOVA) was used to verify the effect of the species, and the Tukey test was used (at a $95 \%$ probability).

\section{RESULTS AND DISCUSSION}

\section{Biomass characterization}

The results of the proximate analysis of the biomass are shown in Table 1.

Table 1. Proximate analysis analysis of the biomass of Bamboo and Eucalyptus.

\begin{tabular}{lccc}
\hline \multicolumn{1}{c}{ Species } & $\begin{array}{c}\text { Carbon } \\
\text { Fixed } \\
(\%)\end{array}$ & $\begin{array}{c}\text { Volatile content } \\
(\%)\end{array}$ & $\begin{array}{c}\text { Ash content } \\
(\%)\end{array}$ \\
\hline B. tuldoides & $21.8 \mathrm{a}(0.6)$ & $75.2 \mathrm{a}(0.7)$ & $3.0 \mathrm{a}(0.1)$ \\
B. vulgaris & $22.8 \mathrm{ab}(0.3)$ & $74.7 \mathrm{a}(0.3)$ & $2.5 \mathrm{ab}(0.2)$ \\
D. asper & $23.0 \mathrm{~b}(0.4)$ & $75.0 \mathrm{a}(0.2)$ & $2.1 \mathrm{~b}(0.3)$ \\
E. urograndis & $17.5 \mathrm{c}(0.2)$ & $82.2 \mathrm{~b}(0.5)$ & $0.3 \mathrm{c}(0.1)$ \\
\hline
\end{tabular}

Means followed by the standard deviation. Means followed by the same letter in the column do not differ by the Tukey test at $5 \%$ significance.

The average levels of carbon of the bamboo species ranged from 21.8 to $23.0 \%$ and were statistically higher than that observed for the Eucalyptus wood $(17.5 \%)$. This result shows an advantage of using bamboo species rather than eucalyptus, once fuels with high fixed carbon content have slower burning, providing longer residence time in burning devices when compared to material with lower fixed carbon contents (Oliveira et al. 2010). Fixed carbon contents support the findings of Brito and Barrichello (1982), who showed bamboo biomass values ranging from $14 \%$ to $25 \%$.

The average levels of volatile material were $75.2 \%$ for B. tuldoides, $74.7 \%$ for B. vulgaris var. vittata, $75.0 \%$ for $D$. asper (without statistical difference) and $82.2 \%$ for E. urograndis. The contents of volatile material of E. urograndis was statistically higher than the contents recorded for the bamboo species. The quantity of volatile material in the wood biomass is usually high, ranging from 65 to $85 \%$ (ARANTES et al., 2013), and is related to burning in the carbonization process, which is faster the higher the content of volatiles. This is one of advantages of biomass relative to mineral coal, which, however, makes the systems designed for the coal combustion not entirely applicable to the combustion of biomass (WERTHER et al., 2000). The amount of volatile materials strongly influences combustion and the thermal decomposition behavior of solid fuels (OBERNBERGER; THEK 2004).

The ash content, representing the material that was not burned, was statistically higher for the biomass of bamboo species (2.1 to 3.0\%) compared to the biomass of E. urograndis $(0.3 \%)$. These results support the findings of Liu et al. (2014). The high ash contents of the bamboo species are related to the high silica contents present in the chemical 
composition of the culms (TAMOLANG et. al., 1980; COSTA, 2004) and represent disadvantages for this biomass compared to Eucalyptus, once the ash can cause damage to the structure of burners. The application in agricultural and forest soils are alternatives for the residue produced in large quantities by the species of bamboo in the form of ashes, during the burning process. Several studies have shown the importance of ashes in increasing soil fertility, mineral nutrition and forest productivity (ZHANG et al., 2002; MAEDA et al., 2008), or as a mineral additive partially replacing Portland cement in concrete due to the high silica content of the material. Such use in cement provides high reactivity and improvements in physical and mechanical properties of the concrete (RODRIGUES et al., 2013).

There is no standardization of solid fuels, such as pellets, in Brazil (CARASCH et al., 2012).
The quality standards in Germany (DIN 51731, 1996), Sweden (SS 187120, 1998) and Austria (M7135, 2000) require ash contents smaller than or equal to $0.5-1.5 \%$ for wood pellets. Therefore, the biomass of the species $B$. tuldoides, $B$. vulgaris var. vittata and $D$. asper, with ash contents above $2 \%$, fall outside of the European quality standards for pellet production.

The average values of the highest calorific value (Table 2) ranged from 4515.1 to 4662.9 kcal. $\mathrm{kg}^{-1}$, with no significant difference among species. The values recorded in this study support findings of Scurlock et al., (2000) and Liu et al. (2014) for bamboo species and by Soares et al., (2015) for E. urograndis. The biomass of bamboo species pellets has satisfactory calorific values for production and marketing in Europe (DIN 51731, 1996; SS 187120, 1998; M7135, 2000) and values similar to wood.

Table 2. Calorific values, bulk density and energy of the biomass

\begin{tabular}{|c|c|c|c|}
\hline Species & $\begin{array}{c}\text { Calorific value } \\
\left(\mathrm{kcal}^{\mathrm{kg}} \mathrm{kg}^{-1}\right)\end{array}$ & $\begin{array}{l}\text { Bulk density } \\
\quad\left(\mathrm{g} \mathrm{cm}^{-3}\right)\end{array}$ & $\begin{array}{c}\text { Energy density } \\
\qquad\left(\text { Gcal. } \mathrm{m}^{-3}\right)\end{array}$ \\
\hline B. tuldoides & $4515.1 \mathrm{a}(38.1)$ & 0.35 a $(0.01)$ & 1.59 a $(0.02)$ \\
\hline B. vulgaris & 4662.9 a $(45.2)$ & $0.29 \mathrm{~b}(0.02)$ & 1.35 b (0.09) \\
\hline D. asper & 4526.2 a $(29.7)$ & $0.25 \mathrm{~b}(0.02)$ & $1.13 \mathrm{~b}(0.02)$ \\
\hline E. urograndis & 4657.6 a (41.2) & $0.26 \mathrm{~b}(0.02)$ & $1.23 \mathrm{~b}(0.10)$ \\
\hline
\end{tabular}

Means followed by the standard deviation. Means followed by the same letter in the column do not differ by the Tukey test at $5 \%$ significance.

The bulk and energy density (Table 2) were directly related with each other. The species $B$. tuldoides, had the highest and significant bulk density value $\left(0.35{\mathrm{~g} . \mathrm{cm}^{-3}}^{-3}\right)$ and the highest energy density (1.59 Gcal.m ${ }^{-3}$ ) (PINHEIRO et al. 2005). Energy density is an important parameter for solid fuels, because it measures the amount of energy stored in a given volume of material. Brand et al. (2005) and Pincelli (2011) evaluated the bulk density of forest harvesting and wood industry residues, and found values for eucalyptus ranging from 0.19 to $0.26 \mathrm{~g} . \mathrm{cm}^{-3}$.

The low energy density of the biomass with respect to oil and coal, implies a high cost of transportation and storage (COUTO et al. 2004). Accordingly, the research and development of techniques aiming at greater concentration of energy per unit volume, as in pelletizing, are key to increase the use of biomass as an energy source. Pellets add value to the final product with compression and increased energy density, promoting easy handling, low humidity, large storage capacity, in addition to the thermal regularity and efficiency during combustion (COUTO et al., 2004; PAULA et al., 2011).

\section{Characteristics of bamboo and eucalyptus pellets}

The results of the pellet characterization analyses are shown in Tables 3 and 4, and consist on the arithmetic mean of 30 pellet measurements for each variable. The biomass used for pellet production had its moisture content adjusted to $20 \%$ (humidity basis), as recommended by the equipment, once water in the material favors heat transfer, and, consequently the link among particles during compaction (QUIRINO et al., 2012). The reduction in the moisture content of the biomass of four species studied, during the pellet manufacturing process, was around $12 \%$, reaching values from 7.5 to $8.2 \%$ after compression. These values are within the optimum levels according to the required quality standards DIN 51731 (1996), SS 187120 (1998) and M7135 (2000). Moisture content influences biomass ignition, as well as the calorific value, once fuel energy is wasted in water evaporation during combustion, also interfering with the durability compressed materials (QUIRINO et al., 2012). 
The diameter and average length of the bamboo and eucalyptus pellets range from 6.0-6.2 $\mathrm{mm}$ and 28.0-29.8 $\mathrm{mm}$, without significant differences among species. The uniformity of pellet dimensions is an important factor in the combustion of the material (LIU et al., 2014). Truly, the combustion rate is more uniform in thinner pellets than in pellets with larger diameter, especially in small ovens (PÄIVI, 2001). The bamboo and eucalyptus pellets produced in this study are in accordance to the required in European quality standards (DIN 51731,1996; SS 187120, 998 and M7135, 2000) in regards to diameter and length.

Table 3. Moisture content, diameter and length of the pellets

\begin{tabular}{cccc}
\hline Species & $\begin{array}{c}\text { Moisture content } \\
(\%)\end{array}$ & $\begin{array}{c}\text { Diameter } \\
(\mathrm{mm})\end{array}$ & $\begin{array}{c}\text { Length } \\
(\mathrm{mm})\end{array}$ \\
\hline B. tuldoides & $7.7 \mathrm{a}(0.5)$ & $6.1 \mathrm{a}(0.1)$ & $28.4 \mathrm{a}(1.3)$ \\
B. vulgaris & $7.5 \mathrm{a}(0.4)$ & $6.1 \mathrm{a}(0.1)$ & $29.8 \mathrm{a}(1.3)$ \\
D. asper & $8.2 \mathrm{a}(0.6)$ & $6.0 \mathrm{a}(0.1)$ & $28.9 \mathrm{a}(1.7)$ \\
E. urograndis & $7.9 \mathrm{a}(0.5)$ & $6.2 \mathrm{a}(0.1)$ & $28.0 \mathrm{a}(1.4)$
\end{tabular}

Means followed by the standard deviation. Means followed by the same letter in the column do not differ by the Tukey test at $5 \%$ significance.

The average bulk density values of the pellets was 0.65 g.cm ${ }^{-3}$ for B. tuldoides, $0.61 \mathrm{~g} . \mathrm{cm}^{-3}$ for B. vulgaris, $0.60 \mathrm{~g} . \mathrm{cm}^{-3}$ for $D$. asper and 0.67 g. $\mathrm{cm}^{-3}$ for E. urograndis and the apparent density of each pellet ranged from 1.15 to $1.38 \mathrm{~g} . \mathrm{cm}^{-3}$, with no significant differences (Table 4). Liu et al. (2012) reported a bulk density variation of bamboo pellets of 0.52 to $0.65 \mathrm{~g} \mathrm{.cm}^{-3}$ and the apparent density of the pellets ranged from 1.05 to $1.20 \mathrm{~g} . \mathrm{cm}^{-3}$, supporting the data obtained in this study. The normative standards of pellets quality, regarding the variables apparent and bulk density, provide values between 1.0 and 1.40 g.cm ${ }^{-3}$ and above $0.6 \mathrm{g.cm}$, respectively (DIN 51731, 1996 and M7135, 2000). Therefore, the bamboo and eucalyptus pellets are consistent with the recommended by European standards.

Table 4. Bulk, apparent and energy density of the pellets.

\begin{tabular}{cccc}
\hline Species & $\begin{array}{c}\text { Bulk density } \\
\left(\mathrm{g} / \mathrm{cm}^{3}\right)\end{array}$ & $\begin{array}{c}\text { Apparent density } \\
\left(\mathrm{g} / \mathrm{cm}^{3}\right)\end{array}$ & $\begin{array}{c}\text { Energy density } \\
\left(\mathrm{Gcal} . \mathrm{m}^{-3}\right)\end{array}$ \\
\hline B. tuldoides & $0.65 \mathrm{a}(0.03)$ & $1.15 \mathrm{a}(0.17)$ & $5.20 \mathrm{a}(1.21)$ \\
B. vulgaris & $0.61 \mathrm{a}(0.05)$ & $1.38 \mathrm{a}(0.24)$ & $6.46 \mathrm{a}(1.52)$ \\
D. asper & $0.60 \mathrm{a}(0.01)$ & $1.36 \mathrm{a}(0.28)$ & $6.17 \mathrm{a}(1.49)$ \\
E. urograndis & $0.67 \mathrm{a}(0.05)$ & $1.36 \mathrm{a}(0.24)$ & $6.36 \mathrm{a}(1.74)$ \\
\hline
\end{tabular}

Means followed by the standard deviation. Means followed by the same letter in the column do not differ by the Tukey test at $5 \%$ significance.

An increase in the magnitude of 327, 478, 546 and $517 \%$ in the energy density of $B$. tuldoides, B. vulgaris, D. asper and E. urograndis biomass, respectively, is observed after the biomass compaction process (production of pellets) (Table 4; Table 2). This increase is due to the increase in biomass density after compression, highlighting the importance of pelletization in using lignocellulosic materials to produce bioenergy, due to the highest concentration of energy per unit volume.

The average durability values were $91 \%$ for B. tuldoides, $98 \%$ for B. vulgaris, $93 \%$ for D. asper and $96 \%$ for E. urograndis (Figure 1), with no statistical difference between the means. Liu et al.
(2014) recorded durability levels of bamboo pellets ranging from 95 to $98 \%$, showing the importance of pellet resistance, especially in the handling and transport.

The "in natura" biomass usually has drawbacks regarding energy use, especially due to its high moisture content, low density and calorific level, causing high transportation and handling costs. However, these problems can be reduced if this biomass is densified, as found in the results obtained for the bamboo and eucalyptus pellets, providing more energy per unit volume, in addition to improving handling and transport (FELFLI et al., 2011; LIU et al., 2014). 


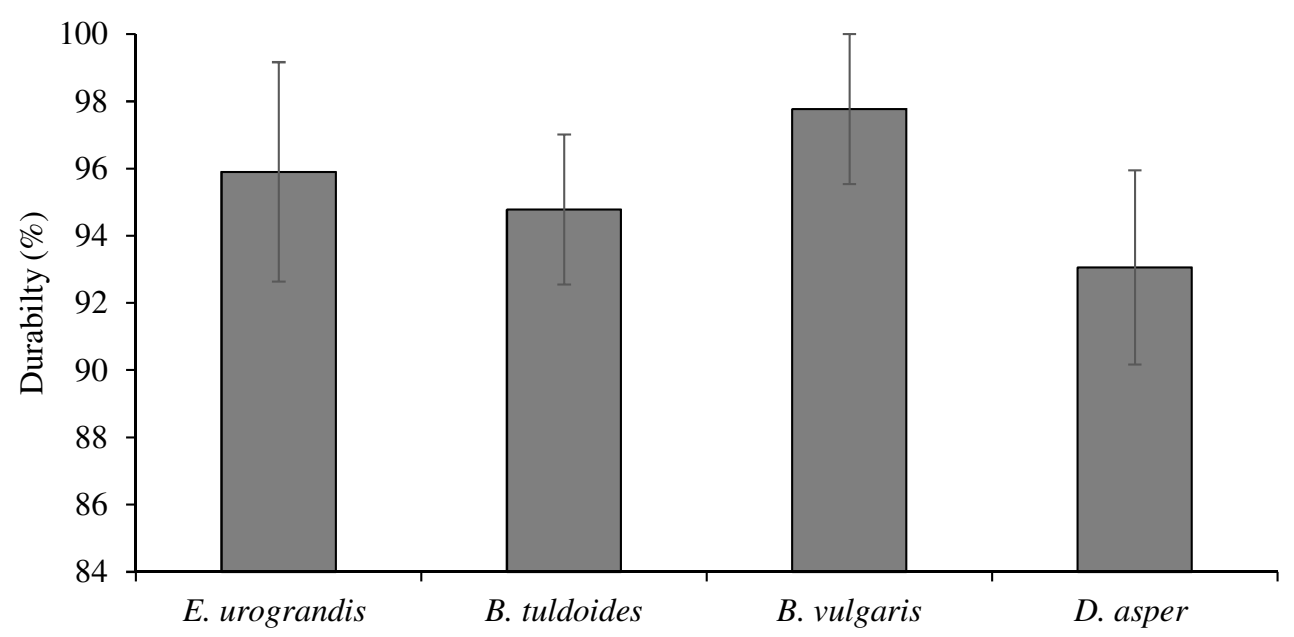

Figure 1. Durability of the bamboo and eucalyptus pellets. The bars indicate the standard deviation from the mean.

Additional research associated with bamboo species are recommended, especially regarding productivity, availability and access to biomass, in order to endorse its use as an alternative energy source.

\section{CONCLUSIONS}

All the characteristics of the bamboo and eucalyptus pellets meet quality specifications required in international marketing standards, except for the ash levels.
The species Bambusa vulgaris var. vitatta, Dendrocalamus asper and Bambusa tuldoides showed energy characteristics that indicate its potential to be used as an energy source in the form of pellets.

\section{ACKNOWLEDGMENTS}

The authors thank CNPq for funding this research - notice number 66/2013 - MCTI/AÇÃO TRANSVERSAL, process number 458300/2013-6.

\section{REFERENCES}

ABIPEL - Associação Brasileira das Indústrias de Pellets. Mapa de Pellets no Brasil. Itapeva. 2013. 4p.

ANEEL. Biomassa. In: Atlas de Energia Elétrica do Brasil. Brasília: Agência Nacional de Energia Elétrica, Brasília. 2013. 74p.

ARRANZ, J. I.; MIRANDA, M. T.; MONTERO, I.; SEPÚLVEDA, F. J.; ROJAS, C. V. Characterization and combustion behaviour of comercial and experimental wood pellets in South West Europe. Fuel. Londres, v. 142, p. 199-207, 2015. http://dx.doi.org/10.1016/j.fuel.2014.10.059

ASSOCIAÇÃO BRASILEIRA DE NORMAS TÉCNICAS - ABNT. NBR 14929. Madeira - Determinação do teor de umidade de cavacos - Método por secagem em estufa. Rio de Janeiro, 2003.

ASSOCIAÇÃO BRASILEIRA DE NORMAS TÉCNICAS - ABNT. NBR 6922. Carvão vegetal - Ensaios físicos - Determinação da massa específica - Densidade a granel. Rio de Janeiro, 1981.

ASSOCIAÇÃO BRASILEIRA DE NORMAS TÉCNICAS - ABNT. NBR 8112. Carvão vegetal - Análise Imediata. Rio de Janeiro, 1986.

ASSOCIAÇÃO BRASILEIRA DE NORMAS TÉCNICAS - ABNT. NBR 8633. Carvão vegetal Determinação do poder calorífico. Rio de Janeiro, 1984. 
BRAND, M. A.; COSTA, V. J.; DURIGON, A.; AMORIN, M. Determinação das propriedades energéticas de resíduos de madeira em diferentes períodos de armazenamento. In: CONGRESSO DE INOVAÇÃO TECNOLÓGICA EM ENERGIA ELÉTRICA. Anais do III Citenel, Florianópolis: Agência Nacional de Energia Elétrica, 2005.

BRITO, J. O.; BARRICHELO, L. E. G. Carvão vegetal de madeira de desbaste de Pinus. IPEF, Piracicaba, 1982.

CARASCHI, J. C.; PINHEIRO, D. G.; VENTORIM, G. Caracterização física e química dos pellets de madeira produzidos no Brasil. In: XIII ENCONTRO BRASILEIRO EM MADEIRAS E EM ESTRUTURAS DE MADEIRA. Anais... Vitória: Universidade Federal do Espírito Santo, jul. 2012.

CARONE, M. T.; PANTALEO, A.; PELLERANO, A. Influence of process parameters and biomass characteristics on the durability of pellets from the pruning residues of Olea europaea L. Biomass and Bioenergy, Oxford, Inglaterra, v. 35, n. 1, p. 402-410, 2011.

COSTA, T. M. S. Estudo da viabilidade técnica do emprego do bambu da espécie Bambusa vulgaris Shard. como carvão vegetal. 2004. 74 p. Dissertação (Mestrado em Ciências de Tecnologia NuclearMateriais) - Autarquia associada à Universidade de São Paulo, São Paulo. 2004.

COUTO, L.; MÜLLER, M. D.; SILVA JÚNIOR, A. G.; CONDE, L. J. N. Produção de pellets de madeira - o caso da Bio-energy no Espírito Santo. Biomassa \& Energia, Viçosa, v. 1, n. 1, p. 45-52, 2004.

DEUTSCHES INSTITUT FÜR NORMUNG - DIN 51731: Testing of solid fuels - Compressed untreated wood, Requirements and testing. Berlin, 1996.

DUCA, D.; RIVA, G.; PEDRETTI, E. F.; TOSCANO, G. Wood pellet quality with respect to EN 14961-2 standard and certifications. Fuel, Londres, v. 135, p. 9-14, 2014. http://dx.doi.org/10.1016/j.fuel.2014.06.042

ESCOBAR, J. F.; COELHO, S. T. O Potencial dos pellets de madeira como energia no Brasil. Jornal Biomassa, Cruzeiro do Iguaçu, v. 3, n. 12, p. 9-14, 2014.

FAO - Forest Products Statistics. Global Forest Products Facts and Figures. 2012.

FELFLI, F. F.; MESA, J. M.; ROCHA, J. D.; FILIPPETTO, D.; LUENGO, C. A.; PIPPO, W. A. Biomass briquetting and its perspectives in Brazil. Biomass and Bioenergy, Oxford, Inglaterra, v. 35, n. 1, p. 236 - 242, 2011.

GARCIA, D. P.; CARASCHI, J. C.; VENTORIM, G. Caracterização energética de pellets de madeira. Revista da Madeira, Curitiba, v. 135, p. 14-18, 2013.

JMP Development Group. JMP Statistics and Graphics Guide, Version 3.1. SAS Institute, Cary, NC. 1997.

LIU, Z. J.; JIANG, Z. H.; CAI, Z. Y.; FEI, B. H.; YU, Y.; LIU, X. E. Effects of carbonization conditions on properties of bamboo pellets. Renewable Energy, Oxford, Inglaterra, v. 51, p. 1-6, 2013.

LIU, Z. J.; JIANG, Z. H.; CAI, Z. Y.; FEI, B. H.; YU, Y.; LIU, X. E. Moisture of bamboo for pellets.

BioResources, Raleigh, Carolina do Norte, v. 7, p. 1548-1557, 2012.

LIU, Z. J.; FEI, B. H.; JIANG, Z. H.; CAI, Z. Y. LIU, X. E. Important properties of bamboo pellets to be used as commercial solid fuel in China. Wood Sci Technol, Nova Iorque, v. 48, p. 903-917, 2014.

LOBOVIKOV, M.; PAUDEL, S.; PIAZZA, M.; REN, H.; WU, J. World bamboo resources. Rome: FAO, 2007. 73 p. 
LYBEER, B. Age-related anatomical aspects of some temperate and tropical bamboo culms (Poaceae: Bambusoideae) Tese (Doutorado em Ciência: Biologia) - Universidade de Gent - Faculdade Wetenschappen. Gent, Holanda, 2006.

O STERREICHISCHES NORMUNGSINSTITUT - O“ NORM M 7135. Compressed wood or compressed bark in natural state - pellets and briquettes, requirements and test specifications. Vienna, Austria, 2000.

MAEDA, S.; SILVA, H. D.; CARDOSO, C. Resposta de Pinus taeda à aplicação de cinza de biomassa vegetal em Cambissolo Húmico, em vaso. Pesquisa Florestal Brasileira, Colombo, n. 56, p. 43-52, 2008.

MOGNON, F.; RODRIGUES, A. L.; SANQUETTA, C. R.; CORTE, A. P. D.; DE NOVAES, A. B; BLUM, C. T. Alocação e modelagem da biomassa em Dendrocalamus asper. Revista Floresta, Curitiba, PR, v. 45, n. 1, p. 1 - 10, jan./mar. 2015.

OLIVEIRA, A. C.; CANEIRO, A. C. O.; VITAL, B. R.; ALMEIDA, W.; PEREIRA, B. L. C.; CARDOSO, M. T. Parâmetros de qualidade da madeira e do carvão vegetal de Eucalyptus pellita F. Muell. Scientia Forestalis, Piracicaba, v. 38, n. 87, p. 431-439, 2010.

PAULA, L. E. R.; TRUGILHO, P. F.; REZENDE, R. N.; ASSIS, C. O.; BALIZA, A. E. R. Produção e avaliação de briquetes de resíduos lignocelulósicos Pesquisa Florestal Brasileira, Colombo, v. 31, n. 66, p. 103-112, 2011.

PINCELLI, A. L. P. S. M. Características dos resíduos da colheita de madeira de eucalipto e pinus, submetidos ao tratamento térmico, com foco na aplicação energética. 2011. 127 p. Tese (Doutorado em Recursos Florestais). Escola Superior de Agricultura "Luiz de Queiroz" - ESALQ/USP, Piracicaba, 2011.

PINHEIRO, G. F.; RENDEIRO, G.; PINHO, J. T. Densidade energética de resíduos vegetais. Biomassa e Bioenergia, Viçosa, v. 2 n. 2, p. 113-123. 2005.

QUIRINO, W. F.; PINHA, I. V. O.; MOREIRA, A. C. O.; SOUZA, F.; TOMAZELLO FILHO, M. Densitometria de raios x na análise da qualidade de briquetes de resíduos de madeira. Scientia Forestalis, Piracicaba, v. 40, n. 96, p. 525-536, 2012.

RODRIGUES, M. S.; BERALDO, A. L.; SAVASTANO JÚNIOR, H.; SANTO, S. F. Cinza de palha de canade-açúcar como adição mineral em fibrocimento. Revista Brasileira de Engenharia Agrícola e Ambiental, v. 17, n. 12, p. 1347- 1354, 2013. http://dx.doi.org/10.1590/S1415-43662013001200014

SANTANA, G. M. Resíduos de bambu para a produção de carvao ativado. 2014. 112p. Dissertação (Mestrado em Ciência e Tecnologia da Madeira). Universidade Federal de Lavras, Lavras/MG, 2014.

SCURLOCK, J. M. O.; DAYTON, D. C.; HAMES, B. Bamboo: An Overlooked Biomass Resource? Environmental Sciences Division, Oak Ridge - Tennessee, v. 19, n. 4, p. 229-244 2000.

SANTI, T. O potencial do bambu: desafios e oportunidades da fibra na produção de celulose e papel e as novas pesquisas sobre seu uso para fins energéticos e geração de biomateriais. Revista de tecnologia em celulose e papel. Ano lxxvi nº 4, abril 2015.

SOARES, V. C.; BIANCHI, M. L.; TRUGILHO, P. F.; HÖFLER, J. PEREIRA, A. J. Análise das propriedades da madeira e do carvão vegetal de híbridos de eucalipto em três idades. Cerne, Lavras, v. 21, n. 2, p. 191-197, 2015.

SWEDISH STANDARDS INSTITUTION - SS 187120. Biofuels and peat fuel pellets classification. Stockholm, Sweden 1998. 
TOSCANO, G.; RIVA, G.; PEDRETTI, E. F.; CORINALDESI, F.; MENGARELLI, C.; DUCA, D. Investigation on wood pellet quality and relationship between ash content and the most important chemical elements. Journal Biomass and Bioenergy, Barking, Inglaterra, v. 56, p. 317-322, 2013.

TAMOLANG, F. N; LOPEZ, F. R.; SEMANA, J. A.; CASIN, R. F.; ESPILOY, Z. B. Properties and utilization of Philippine erect bamboos. Forpride digest, Laguna, v. 99, n. 34, p. 31-41, 1980.

WERTHER, J.; SAENGER, M.; HARTGE, E.U.; OGADA, T.; SIAGI, Z. Combustion of agricultural residues. Progress in Energy and Combustion Science. Hamburg, Germany, v. 26, n. 1, p. 1-27, 2000.

ZHANG, F. S.; YAMASAKI, S.; NANZYO, M. Waste ashes for use in agricultural production: I. Liming effect, contents of plants nutrients and chemical characteristics of some metals. Science Total Environment, v. 284, p. 215-225, 2002. http://dx.doi.org/10.1016/S0048-9697(01)00887-7 